\section{Maglev track}

$¥ 1$ million million a year. The powerful Ministry of Finance is thus strongly opposed to any plan that could place a further burden on Japanese taxpayers. The cost of a Tokyo-Osaka Maglev line is variously estimated at between $¥ 3$ million million and $¥ 10$ million million.

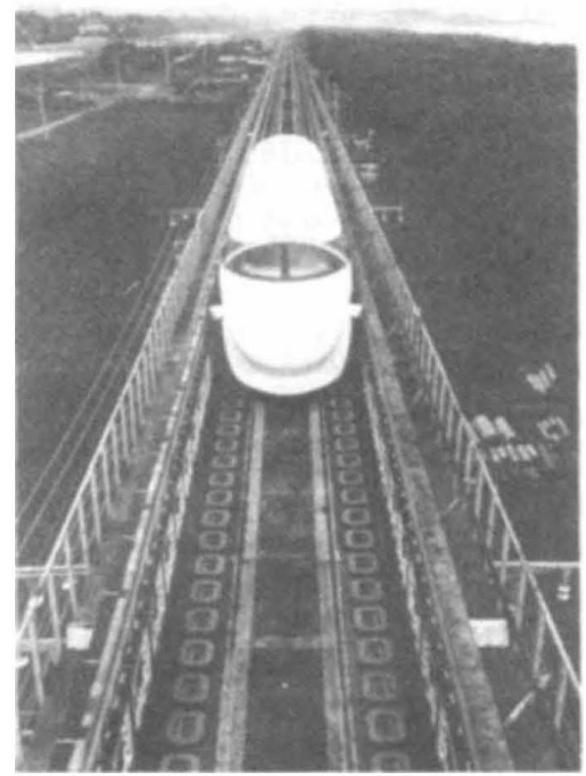

Maglev, up to 500 kilometres an hour? (Railway Technical Research Institute.)

Nevertheless, there is strong support among the ruling Liberal Democratic Party for building a Maglev line and more Shinkansen. JNR's debt has been quietly forgotten by most of the Japanese public and there is a saying among politicians that if you get a Shinkansen (or Maglev) station located in your constituency you are assured a place in the Diet for life.

David Swinbanks

\title{
Threats against witness
}

\section{Washington}

THREATS of legal action against a witness who testified at the most recent US congressional hearing on scientific misconduct have incurred the wrath of Congressman John Dingell, chairman of the House of Representatives subcommittee on oversight and investigations. As a staunch defender of the whistleblower in cases of misconduct, Dingell said he was "greatly concerned by what appear to be threats" and demanded evidence to justify them.

The incident was prompted by statements made by Dr Robert Sprague of the University of Illinois at Urbana-Champaign at a House of Representatives subcommittee hearing in June. Sprague, who exposed the fraudulent research of psychologist Stephen Breuning, said that the University of Pittsburgh tried to cover up the misconduct.

The vice-president and counsel for the medical and health care division of the University of Pittsburgh, George Huber, then wrote an angry letter to Sprague accusing him of making statements which were "not only inaccurate and untrue, but also slanderous and libelous". He said Sprague should stop making false statements about the university and should retract the inaccurate portions of his testimony, otherwise the university would take "whatever lawful corrective measures are necessary and appropriate, including the filing of legal action".

When Dingell heard of the letter, he responded with an equally angry letter to the president of the university, Wesley Posvar, expresssing his astonishment and saying he believed that Sprague's testimony was "substantially accurate". A

\section{CONSERVATION}

\section{Biodiversity plan gets backing from NSF}

\section{Washington}

LAST week, the US National Science Foundation (NSF) gave its backing to an ambitious plan to help preserve the Earth's biological diversity and halt what it calls "the most catastrophic loss of species in the last 65 million years". But the plan is likely to face an uphill struggle for funds in Congress.

In a report endorsed last week by the National Science Board entitled Loss of biological diversity: a global crisis requiring international solutions, NSF's committee on international science says that the foundation should increase funds for basic research in conservation biology, restoration ecology and environmental management, undertake an inventory of all living organisms, especially microorganisms, and increase support for research on biodiver- sity in developing countries.

To implement the plan would require in the first year a doubling of funds for biodiversity research, currently $\$ 20$ million a year, followed by further annual increases until expenditure reached about $\$ 75$ million. The 1990 budget includes a request for $\$ 30$ million, but that is unlikely to be met in full.

NSF says that it should take the initiative in the study of global biodiversity because at present it provides the major part of federal support for systematics and ecology research in colleges and universities. The announcement of the new plan is likely to pre-empt attempts in Congress to set up a National Center for Biological Diversity and Environmental Research within the Smithsonian Institution.

Christine McGourty week later, after a prompt review of the matter, Posvar informed Dingell that although there was no evidence of a coverup, the university's investigation was not carried out with "sufficient zeal". He also wrote to Sprague, apologizing for the letter and commending him for his "vigilance and initiative on behalf of academic integrity".

Sprague says he criticized the university because its first three investigations focused only on research carried out by Breuning under subcontract to the University of Illinois and failed to scrutinize the research carried out for the University of Pittsburgh. No fraud was found in Breuning's research at the University of Pittsburgh until a fourth investigative committee reported on the matter in 1985 , 18 months after Sprague's first accusations. By that time, Breuning had resigned, having admitted falsifying data related to his previous work with Sprague at the University of Illinois.

The university's counsel, Lewis Popper, who carried out the review, admits that it is "somewhat difficult to understand" why the university did not document and expose the fabrication of data at Pittsburgh and he says the university can be "legitimately criticized" for not doing so. Sprague's "impatience and ire" are understandable, he says. But he maintains that there is no evidence of an intentional cover-up. One reason why the committees might not have examined research at the University of Pittsburgh is that Sprague's initial allegations and proof focused on research carried out for the University of Illinois, says Popper. But Sprague says that the evidence supplied to the university was "equally devastating in both cases". For the investigations to ignore the research at the University of Pittsburgh was "mighty strange", he says. "I don't know how that could be explained by incompetence."

Popper also says that because Breuning had already resigned, it was difficult to investigate him and "arguably futile" to sanction him; that research was at an early stage and was terminated before he left; that the public health threat from fraudulent research at Pittsburgh was small compared with the risk from the research under subcontract to the University of Illinois, although Sprague disputes this; and that at that time there was less sensitivity and experience with investigating research misconduct that exists today. Because there is no evidence for a coverup, Popper says, Sprague could be "legally vulnerable" if he repeated his accusations.

Sprague now says he will not repeat the allegations in future but will merely show his evidence and let others draw their own conclusions.

Christine McGourty 